\title{
PEMBELAJARAN BAHASA JEPANG DI LEMBAGA PELATIHAN KERJA (LPK) BULAN PALAPA DESA LANDIH BANGLI
}

\author{
N. L. M. Sari ${ }^{1}$, I. W. Sadyana ${ }^{2}$, N.N. Suartini ${ }^{3}$ \\ ${ }^{123}$ Jurusan Pendidikan Bahasa Jepang, Universitas Pendidikan Ganesha, Singaraja, Bali \\ e-mail: sakukuratamitha@gmail.com, wayan.sadyana@undiksha.ac.id, nnsuartini@undiksha.ac.id
}

\begin{abstract}
Abstrak
Penelitian ini bertujuan untuk mendeskripsikan 1) metode pembelajaran yang digunakan dalam proses pembelajaran bahasa Jepang di LPK Bulan Palapa, 2) strategi pembelajaran yang digunakan dalam proses pembelajaran bahasa Jepang di LPK Bulan Palapa, 3) kendala yang dihadapi dalam proses pembelajaran bahasa Jepang di LPK Bulan Palapa. Subjek pada penelitian ini adalah dua orang pengajar bahasa Jepang di LPK Bulan Palapa. Pengumpulan data dalam penelitian ini dilakukan dengan metode wawancara, observasi, dan dokumentasi. Data yang diperoleh dianalisis dengan menggunakan metode deskriptif kualitatif. Hasil penelitian ini menunjukkan bahwa (1) metode yang digunakan dalam pembelajaran bahasa Jepang di LPK Bulan Palapa yaitu GTM, direct method, dan metode audiolingual. (2) strategi yang digunakan dalam pembelajaran bahasa Jepang yaitu strategi drill, tanya jawab, dan pemberian tugas. (3) kendala yang dihadapi dalam pembelajaran bahasa Jepang di LPK Bulan Palapa yaitu kemampuan pemahaman siswa yang berbeda-beda.
\end{abstract}

Kata kunci: Metode pembelajaran, Strategi pembelajaran, Pembelajaran di LPK

要旨

本研究の目的は 1) ブラン・パラパ技能訓練協会における日本学習法、2)日本学習のストラテ ジー，3)日本学習の問題点を明らかにすることである。調査対象はブラン・パラパ技能訓練協会の日 本語教師である。データ収集方法は観察、インタビュー、及び教授法、教科書、教材などである。そ れを定性的な記述法により分析した。結果、1)指導法は GTM、ダイレクト法、視聴覚方法、2) 日本 学習法はドリル、応答練習、習得のタスク、3) 問題点として、学習者の理解力はざまざまであるこ とが分かった。

キーワード : 学習法、授業のストラテジー、ブラン・パラパ技能訓練協会の学習

\section{Pendahuluan}

Bahasa Jepang merupakan pembelajaran bahasa asing yang peminatnya tinggi di Indonesia. Pembelajaran bahasa Jepang sudah diterapkan di pendidikan formal seperti Sekolah Dasar (SD), Sekolah Menengah Pertama (SMP), Sekolah Menengah Atas (SMA), Sekolah Menengah Kejuruan (SMK), Perguruan Tinggi (PT). Namun juga diterapkan di pendidikan non formal seperti lembaga kursus atau Lembaga Pelatihan Kerja (LPK). Pembelajaran bahasa Jepang sudah mengalami peningkatan yang signifikan dari tahun ke tahun. Peningkatan dapat dilihat dari segi jumlah pembelajar maupun segi lembaga penyelenggara.

Seiring dengan peningkatan jumlah pembelajar bahasa Jepang, jumlah institut pendidikan bahasa Jepang di Indonesia juga ikut meningkat dari 2.496 institut di tahun 2015 menjadi 2.879 institut di tahun 2018 (The Japan Foundation, 2018). Hal yang mendorong pelajar berminat untuk belajar bahasa Jepang dipengaruhi oleh pembelajar yang ingin berkomunikasi dalam bahasa Jepang, ingin berinteraksi dengan orang Jepang, budaya, musik, anime dan manga. Selain itu, bekerja di Jepang juga menjadi motivasi dalam belajar bahasa Jepang. Untuk dapat bekerja di Jepang diharapkan mempunyai keahlian atau keterampilan diri. Bagi yang mempunyai keinginan untuk dapat bekerja ke Jepang harus memiliki kualitas atau kemampuan. Upaya yang dapat diberikan yaitu dengan memberikan 
JPBJ, Vol. 7 No. 1, Februari 2021

ISSN: 2613-9618

pelatihan kepada calon tenaga kerja melalui pendidikan nonformal yaitu melalui pendidikan lembaga pelatihan.

Lembaga pelatihan atau sering disebut dengan LPK (Lembaga Pelatihan Kerja) merupakan lembaga yang digunakan untuk meningkatkan keterampilan tertentu. LPK ini digunakan sebagai jalur dalam memperkerjakan tenaga kerja di luar dan di dalam negeri. Dalam DPN SBMI (2020) di provinsi Bali dari 246 LPK terdaftar terdapat 24 LPK yang memiliki izin dalam pengiriman pemagangan Jepang yang telah teregistrasi di Direktorat Pemagangan Kementerian Ketenagakerjaan.

Pada pembelajaran di Lembaga Pelatihan Kerja (LPK) sudah memiliki metode dan strategi tertentu yang disesuaikan dengan tujuan pelaksanaan pelatihan tersebut. Supaya metode dan strategi dapat terealisasikan dengan baik, maka dibutuhkan tenaga pengajar yang sesuai dengan bidangnnya. Tenaga pengajar ini harus mempunyai kualitas dalam mengajar sehingga mampu meningkatkan kemampuan siswa dalam bahasa Jepang. Pengajar dapat memilih dan menggunakan metode dan strategi yang tepat dalam proses pembelajaran sangat membantu siswa dalam memahami suatu materi yang diberikan, dan proses pembelajaran bahasa Jepang menjadi terarah dan tujuan pembelajaranpun dapat tercapai. Terdapat berbagai metode dan strategi pembelajaran, maka pengajar harus mampu menerapkan metode dan strategi tersebut sesuai dengan tipe belajar dan kondisi di LPK, sehingga tujuan yang telah dirumuskan dapat tercapai. Pada hakikatnya semakin bervariasi metode dan strategi pembelajaran yang diterapkan, maka semakin dekat dengan pencapaian tujuan pembelajaran.

Pada penelitian ini, berfokus membahas tentang pembelajaran bahasa Jepang di LPK Bulan Palapa. Hal yang melatarbelakangi LPK Bulan Palapa dijadikan sebagai tempat penelitian adalah salah satu LPK yang mengadakan pembelajaran bahasa Jepang dan sekaligus memberikan peluang magang ke Jepang. LPK ini tergolong banyak diminati dan aktif dalam mengirimkan tenaga kerja ke Jepang. LPK Bulan Palapa memiliki 4 kelas kursus dengan jumlah siswa disetiap kelas mencapai 25 orang. LPK Bulan Palapa yang berdiri sejak tahun 2013 dan hingga tahun 2019 sudah memberangkatkan tenaga kerja kurang lebih 155 siswa ke berbagai wilayah di Jepang. Siswa yang diberangkatkan ke Jepang merupakan siswa yang lulus dari tes interview. Tes dilakukan sesuai dengan kebutuhan dari koperasikoperasi penyalur tenaga kerja yang bekerja sama dengan LPK Bulan Palapa. Pemberangkatan siswa magang ke Jepang dilakukan secara bertahap, dalam 1 tahun pemberangkatan dilakukan sebanyak 5 kali yaitu pada bulan Januari, Maret, Juli, Agustus dan November.

Dari hasil wawancara, pembelajaran bahasa Jepang di LPK Bulan Palapa hampir sama seperti pembelajaran bahasa Jepang pada umumnya, yaitu mempelajari bahasa Jepang dasar bagi siswa kelas kursus. Selain bahasa Jepang, siswa juga diajarkan berbagai keterampilan yang sesuai dengan keperluan magang ke Jepang untuk siswa kelas karantina. Pemberian materi setiap pertemuan dalam 1 minggu hanya membahas 1 bab materi yang diambil dari buku Minna no nihongo 1 edisi 2. Materi diajarkan sudah terjadwal, seperti hari senin diajarkan pengenalan kosakata, selasa diajarkan bunpou atau tata bahasa, rabu diajarkan latihan dan percakapan, kamis diajarkan kata benda, kata keterangan, kata kerja dan kata sifat, dan jumat diajarkan budaya Jepang dan ulangan. Pengajar di LPK Bulan Palapa merupakan peserta magang ke Jepang. Pengajar mengajarkan pembelajaran bahasa Jepang dasar pada kelas kursus dan kaiwa dan bunpou pada kelas karantina.

Dalam proses pembelajaran bahasa Jepang di kelas, pengajar menggunakan bahasa Indonesia dan bahasa Jepang, kadang-kadang juga menggunakan bahasa daerah. Ketika siswa menjawab pertanyaan, membuat soal dan mengucapkan kosakata dengan benar pengajar memberikan respon baik kepada siswa, apabila salah siswa akan diberikan kesempatan untuk mengulang baik dalam menjawab pertanyaan, membuat soal dan mengucapkan kosakata. Selama proses pembelajaran, siswa ditunjuk satu persatu untuk mengucapkan kosakata, membuat kalimat, menjawab soal yang ada pada buku kemudian menterjemahkan ke dalam bahasa Indonesia. Siswa selalu diberikan kesempatan untuk membuat contoh kalimat sesuai dengan meteri yang diajarkan kemudian mengomunikasikan, sehingga pembelajaran bahasa Jepang tidak monoton pada buku pelajaran. Hal ini dapat 
JPBJ, Vol. 7 No. 1, Februari 2021

ISSN: 2613-9618

memberikan dampak pada kemampuan siswa dalam menggunakan tata bahasa untuk berkomunikasi pada situasi sebenarnya.

Pengajar bahasa Jepang di LPK Bulan Palapa telah mengajar selama kurang lebih tiga tahun. Pendidikan pengajar tidak berasal dari sekolah formal, namun merupakan peserta yang pernah magang ke Jepang. Selain itu, pengajar juga sering mengikuti pelatihanpelatihan bagi pengajar pemula. Dari pengalaman tersebut, pengajar mampu memberikan contoh cara mengajar bagi pengajar lainnya. Sehingga memberikan kemajuan bagi pengajar dalam mengajar di kelas. Pengajaran bahasa Jepang dilaksanakan selama 3 bulan yang terbilang singkat yaitu dalam seminggu terdapat 5 kali pertemuan. Dalam satu kali pertemuan terdapat alokasi waktu 4 jam. Meskipun waktu yang dapat dikatakan singkat, siswa mampu mencapai target pembelajaran. Hal tersebut di dukung oleh pengajar dalam menggunakan metode maupun strategi pembelajaran bahasa Jepang yang digunakan demi mendukung tercapainya tujuan pembelajaran. Oleh karena itu, penelitian mengenai pembelajaran bahasa Jepang di LPK Bulan Palapa penting untuk dilakukan.

Penelitian yang terkait tentang pembelajaran bahasa Jepang di LPK yaitu dari Astina (2019) yang berfokus di LPK Terakoya Bali yang meneliti tentang strategi pembelajaran bahasa Jepang dan faktor yang mendasari penggunaan strategi pembelajaran bahasa Jepang. Hasil penelitian menunjukkan bahwa strategi yang digunakan oleh pengajar bahasa Jepang yaitu drill, tanya jawab dan role play. Faktor-faktor yang mendasari penggunaan strategi pembelajaran yaitu kurangnya keberanian siswa untuk berbicara dan tuntutan pembelajaran yang mengharuskan siswa menguasai bahasa Jepang dengan cepat dan dalam jangka waktu yang singkat.

Penelitian tersebut sejalan dengan penelitian pembelajaran bahasa Jepang di LPK Bulan Palapa yaitu meneliti tentang strategi pembelajaran dan meneliti di lembaga pelatihan. Bedanya penelitian ini yaitu menjelaskan metode pembelajaran dan kendala yang dihadapi dalam pembelajaran bahasa Jepang di LPK Bulan Palapa.

Penelitian ini berfokus pada pembelajaran bahasa Jepang di kelas kursus mengenai metode dan strategi pembelajaran yang digunakan. Tujuan pembelajaran ini ketika siswa selesai mengikuti pelatihan ialah siswa diharapkan mampu memahami dan menguasai cara tulis, cara baca, pengucapan dan penggunaan pola kalimat bahasa Jepang serta mampu dalam mengomunikasikan dalam situasi nyata.

Penelitian ini penting dilakukan yaitu untuk membantu dalam mendeskripsikan metode dan strategi pembelajaran yang digunakan oleh pengajar. Penggunaan metode dan strategi pembelajaran yang tepat dapat mempermudah proses pembelajaran sehingga siswa memahami materi yang disampaikan dengan efektif. Selain itu, dapat meningkatkan motivasi dan minat siswa dalam mengikuti proses pembelajaran. Dengan adanya penelitian ini, pengajar juga dapat menjadikannya sebagai gambaran dalam memilih dan/atau menggunakan metode dan strategi pembelajaran pada proses mengajar.

Berdasarkan latar belakang tersebut, maka rumusan masalah dari penelitian ini yaitu (1) Metode pembelajaran apa saja yang diterapkan dalam pembelajaran bahasa Jepang di LPK Bulan Palapa?, (2) Strategi pembelajaran apa saja yang diterapkan dalam pembelajaran bahasa Jepang di LPK Bulan Palapa? (3) Kendala apa saja yang dihadapi dalam mengajar bahasa Jepang di LPK Bulan Palapa?

Penelitian ini menggunakan beberapa teori dalam mendukung proses penelitian antara lain 1) Lembaga Pelatihan Kerja (LPK), 2) pendidikan nonformal, 3) metode pembelajaran bahasa asing, 4) strategi pembelajaran bahasa asing, dan 5) kendala dalam pembelajaran.

Lembaga Pelatihan Kerja (LPK) merupakan program pendidikan nonformal yang diselenggarakan bagi masyarakat uyang memerlukan bekal pengetahuan, keterampilan, mengembangkan profesi, dan/atau melanjutkan kejenjang lebih tinggi (Septyana, 2013). Penyelenggaraan LPK digunakan untuk melatih keterampilan kerja (soft skill) bagi masyarakat.

Menurut Romadhon, 2018 pendidikan nonformal merupakan pendidikan yang berada di luar pendidikan formal dengan tujuan agar siswa mendapatkan bimbingan dan tujuan belajar demi meningkatkan keterampilan diri. Pendidikan nonformal dapat digunakan untuk 
mengembangkan kualitas dan meningkatkan sumber daya manusia. Sehingga dibutuhkan waktu yang fleksibel dalam menyelenggarakan pendidikan nonformal ini.

Metode pembelajaran bahasa asing digunakan dalam menyampaikan bahan pelajaran saat berinteraksi dengan siswa. Beberapa metode pembelajaran bahasa, yaitu (a) GTM (Grammar Translation Method), yaitu metode menterjemahkan tata bahasa (Padmadewi, 2012), (b) Direct Method, yaitu bahasa asing digunakan secara langsung dalam pembelajaran (Padmadewi, 2012), (c) Metode audiolingual, yaitu metode untuk membentuk kemampuan mendengar dan berbicara (Fuadah, 2014), (d) TPR (Total Physical Response), yaitu metode melalui perintah, ucapan dan gerakan tubuh (Astutik, 2017), (e) Community Language Learning (CLL) atau metode konseling, yaitu metode yang menjadikan guru sebagai konselor (Lailaa, 2016), dan (f) Communicative Language Teaching (CLT), yaitu metode agar siswa mampu menggunakan bahasa asing secara komunikatif (Budiarso, 2019).

Strategi pembelajaran yaitu suatu rencana kegiatan yang digunakan dalam proses pembelajaran. Beberapa strategi pembelajaran yaitu (a) Ceramah, yaitu penyampaian materi dengan penuturan langsung secala lisan (Tambak, 2014), (b) Diskusi, yaitu strategi yang saling bertukar pendapat dari suatu pertanyaan (Irwan,dkk, 2018), (c) Kerja kelompok, yaitu kegiatan kelompok dalam menyelesaikan masalah (Kartikasari, 2017), (d) Tanya jawab, yaitu penyajian materi pelajaran dalam bentuk pertanyaan kemudian dijawab oleh siswa (Basrudin,dkk, 2013), (e) Pemecahan masalah, yaitu strategi yang digunakan dalam pembelajaran untuk menyelesaikan masalah yang ada (Sulasamono, 2012), (f) Kooperatif, yaitu strategi dengan memberikan kesempatan kepada siswa untuk mencapai keberhasilan belajar yang maksimal (Sodiqin, 2015), (g) Drill, yaitu latihan dengan praktik secara berulang-ulang (Sari, 2016), (h) Pemberian tugas, yaitu strategi yang ditandai dengan tugas yang diberikan guru untuk dikerjakan oleh siswa baik di sekolah atau di rumah (Adiatman, 2011), dan (i) Role play, yaitu strategi dengan menirukan atau memperagakan peristiwa susuai dengan materi pelajaran (Anggriani, 2017).

Hambatan dalam proses pembelajaran berasal dari faktor internal dan eksternal. Faktor internal berupa minat, motivasi, kemampuan siswa, keterampilan guru mengajar. Sedangkan faktor eksternal berupa keadaan sekolah, media pembelajaran dan alat peraga.

Teori yang telah dipaparkan di atas digunakan sebagai bahan perbandingan untuk dapat mendeskripsikan metode pembelajarang yang digunakan, strategi pembelajaran yang digunakan, dan kendala yang dihadapi dalam pembelajaran bahasa Jepang di LKP Bulan Palapa.

\section{Metode}

\section{a. Sumber Data}

Sumber data dalam penelitian ini diperoleh melalui wawancara dan observasi secara langsung dengan pengajar bahasa Jepang di LPK Bulan Palapa. Selain itu, untuk memperkuat dan melengkapi informasi dari wawancara dan observasi juga bersumber dari RPP, silabus, dan bahan ajar yang digunakan pada saat proses pembelajaran bahasa Jepang di LPK Bulan Palapa.

Subjek dalam penelitian ini yaitu pengajar bahasa Jepang di LPK Bulan Palapa. Sedangkan objek dalam penelitian ini yaitu (1) Metode pembelajaran yang digunakan dalam pembelajaran bahasa Jepang di LPK Bulan Palapa, (2) Strategi pembelajaran yang digunakan dalam pembelajaran bahasa Jepang di LPK Bulan Palapa, dan (3) Kendala yang dihadapi dalam pembelajaran bahasa Jepang di LPK Bulan Palapa. Dari ketiga hal pokok tersebut, itulah yang menjadi sasaran utama dalam penelitian ini.

\section{b. Teknik Pengumpulan Data}

Dalam penelitian ini, teknik atau metode pengumpulan data yang digunakan ialah wawancara, observasi dan dokumentasi.

Wawancara yang digunakan pada penelitian ini adalah wawancara mendalam dan terbuka. Pengumpulan data melaui wawancara dilakukan dengan tanya jawab dengan 
pengajar bahasa Jepang di LPK Bulan Palapa. Tanggal pelaksanaan wawancara dilakukan pada 28 November 2019, 11 Desember 2019, 20 Januari 2020, 21 Januari 2020 dan 4 Maret 2020.

Observasi yang digunakan non-partisipan artinya tidak ada partisipasi langsung ke dalam proses pembelajaran. Observasi dilakukan sebanyak 3 kali di ruang kelas $A$ yaitu pada senin, 20 Januari 2020, selasa, 21 Januari, dan rabu, 4 maret 2020.

Dokumentasi yang dilakukan untuk pengumpulan data menggunakan berupa mendokumentasikan RPP, silabus, bahan ajar, serta foto-foto pada saat proses pembelajaran bahasa Jepang dari awal sampai akhir pembelajaran di LPK Bulan Palapa .

\section{c. Teknik Analisis Data}

Dalam penelitian ini terdapat beberapa teknis analisis data yang digunakan, antara lain (1) Tabulasi data, yaitu menggabungkan hasil data wawancara dan observasi, (2) Reduksi data, yaitu merangkum hal-hal pokok yang penting dari hasil observasi dan wawancara, (3) Deskripsi data yaitu menyajikan data secara deskriptif agar sesuai dengan rumusan masalah, (4) Klasifikasi data yakni data dikelompokkan sesuai dengan jenis dan tujuannya, (5) Penarikan kesimpulan yaitu seluruh data yang sudah ditemukan dilapangan yang merupakan jawaban dari rumusan masalah akan disimpulkan.

\section{d. Pengecekan Keabsahan Data}

Dalam penelitian ini, pengecekan keabsahan data digunakan dengan teknik triangulasi data. Triangulasi data yang digunakan pada penelitian ini ialah triangulasi sumber data dan triangulasi teori. Triangulasi sumber data didapat dariteknik wawancara dan observasi serta teknik dokumentasi. Sedangkan triangulasi teori dilakukan dengan membandingkan teroti yang telah dicantumkan pada kajian teori dengan data yang diperoleh dari hasil observasi.

\section{Hasil dan Pembahasan}

\section{Hasil Observasi}

Observasi pertama dilakukan pada 20 Januari 2020 di kelas kursus pada pukul 08.00-13.00 WITA dengan materi bab 16 dalam buku minna no nihongo I. Materi yang dibahas pada bab 16 yaitu memperkenalkan kosakata baru.

Observasi kedua dilakukan pada 21 Januari 2020 di kelas kursus pada pukul 08.0013.00 dengan materi bab 16 pada buku minna no nihongo I. Materi yang dibahasa yaitu pola kalimat.

Observasi ketiga dilakukan pada 4 Maret 2020 di kelas kursus pada pukul 08.0013.00 dengan materi kaiwa bab 10-25 pada buku minna no nihongo I. Materi yang dibahas yaitu ga arimasu/imasu, joshuushi (hitotsu, futatsu-), bentuk kata sifat dan benda menurut waktu (deshita, dewa arimasen, dewa arimasendeshita), ga hoshii, te kudasai, te mo iidesu, kegiatan yang berturut-turut (KK te,KK te-), kata kerja bentuk negatif (nal), koto ga dekimasu, kata kerja bentuk lampau (ta), teneikei dan futsukei, to omoimasu, keterangan kata benda oleh anak kalimat, toki, kuremasu dan tara.

\section{Hasil Wawancara}

Wawancara dilakukan dilakukan pada tanggal 28 November 2019 dan 11 Desember 2019 di ruang tamu LPK Bulan Palapa. Selain itu, wawancara juga dilakukan pada tanggal 20 Januari 2020, 21 Januari 2020 dan 4 Maret 2020 disela-sela waktu istirahat pembelajaran bahasa Jepang. Adapun hasil wawancara yang diperoleh dari dua pengajar bahasa Jepang di LPK Bulan Palapa, sebagai berikut.

Pembelajaran di LPK Bulan Palapa adalah pembelajaran yang dikhususkan untuk mempelajari bahasa Jepang dan tidak ada bahasa lain yang diajarakan di LPK Bulan Palapa. Pembelajaran bahasa Jepang di LPK Bulan Palapa dilaksanakan pada setiap hari senin sampai jumat selama enam jam yaitu dari pukul 08.00-13.00 WITA. Dalam proses pembelajaran, pengajar maupun siswa menggunakan buku penunjang yaitu Minna no 
JPBJ, Vol. 7 No. 1, Februari 2021

ISSN: 2613-9618

Nihongo 1 agar mempermudah dalam proses pembelajaran. Pembelajaran bahasa Jepang di LPK Bulan Palapa digunakan pelatihan bagi yang mempunyai keinginan dan niat yang besar untuk mencari pengalaman bekerja di Jepang maksimal 3 tahun dalam sekali pemagangan.

Pembelajaran bahasa Jepang di LPK Bulan Palapa lebih menekankan pada kaiwa atau keterampilan berbicara bagi kelas karantina. Sedangkan bagi kelas kursus pembelajaran dimulai dari mempelajari huruf hiragana dan katakana, pengenalan kosakata. Untuk mempelajari huruf hiragana dan katakana dibutuhkan waktu kurang lebih 2 minggu. Siswa dituntut menghafalkan huruf hiragana dan katakana agar memudahkan siswa dalam belajar bahasa Jepang. Siswa juga menggunakan tulisan romaji dan juga terjemahan untuk memudahkan siswa dalam mengerti bahasa Jepang.

Kegiatan yang sering dilakukan pengajar dalam melatih kemampuan bahasa Jepang siswa ialah dengan melatih pengucapan siswa, melatih soal yang ada pada buku minna no nihonggo I. Dengan memberikan latihan- latihan tersebut secara berlahan kemampuan bahasa Jepang siswa akan meningkat.

Dalam penugasan yang dilakukan oleh pengajar dengan memberikan tugas menghafalkan kosakata, membuat kalimat dan menjawab soal yang ada di buku. Penugasan tersebut akan digunakan sebagai bahan melaksanakan tes untuk siswa sebelum memulai pembelajaran. Bentuk penugasan yang diberikan oleh pengajar seperti tugas individu. Tugas individu yang diberikan seperti latihan dengan menjawab soal-soal yang ada di buku penunjang. Sedangkan siswa juga diberikan tugas kelompok dengan membuat percakapan. Penugasan ini dimaksudkan agar siswa tidak melupakan kosakata dan makna pola kalimat yang telah diajarkan.

Dalam proses pembelajaran, pengajar selalu melibatkan siswa dalam membuat dan membaca contoh soal yang kemudian diterjemahkan ke dalam bahasa Indonesia. Selain itu, pengajar juga menanyakan arti kosakata pada kalimat tersebut. Hal ini dilakukan agar siswa mampu berbahasa Jepang dan menterjemahkan ke dalam bahasa Indonesai.

Dalam menjelaskan pola kalimat oleh pengajar dilakukan secara langsung dan ditulis di papan tulis. Untuk lebih mudah dalam memahami maksud dari pola kalimat, pengajar menggunakan contoh-contoh kalimat. Latihan yang sering dilakukan ialah membuat kalimat, menjawab soal pada buku penunjang dan percakapan.

\section{Pembahasan}

Berdasarkan hasil observasi pertama dan ketiga di kelas A bagi siswa yang kursusmengenai pembelajaran bahasa Jepang di Lembaga Pelatihan Kerja (LPK) Bulan Palapa desa Landih Bangli, menemukan bahwa pengajar menggunakan beberapa metode dalam pembelajaran bahasa Jepang. Metode pembelajaran tersebut, antara lain.

\section{1) Grammar Translation Method (GTM)}

Dalam proses pembelajaran bahasa Jepang di kelas, pengajar masih menggunakan metode GTM. Metode GTM lebih menekankan pada kemampuan siswa dalam melafalkan dan menterjemahkan kosakata dan tata bahasa. Penerapan yang dilakukan oleh pengajar dengan melafalkan dan menterjemahkan dari bahasa Indonesia ke dalam bahasa Jepang atau sebaliknya dari bahasa Jepang ke dalam bahasa Indonesia. Penggunaan metode ini terlihat pada observasi pertama sampai observasi ketiga.

Penggunaan metode GTM oleh pengajar ketika memberikan intruksi kepada siswa untuk membaca kalimat bahasa Jepang kemudian menterjemahkan ke dalam bahasa Indonesia. Kegiatan tersebut berupa membaca contoh kalimat dan menjawab soal pada buku minna no nihonggo I. Metode ini juga digunakan saat memperkenalkan kosakata baru. Pengajar akan menyebutkan kosakata dalam bahasa Jepang siswa menterjemahkan dalam bahasa Indonesia, begitu juga sebaliknya guru menyebutkan dalam bahasa Indonesia siswa menterjemahkan dalam bahasa Jepang.

Metode GTM juga digunakan ketika tes kecil pada saat memperkenalkan kosakata baru. Tes yang diberikan berupa menterjemahkan kosakata yang sudah dijelaskan. Tes ini 
JPBJ, Vol. 7 No. 1, Februari 2021

ISSN: 2613-9618

digunakan sebagai latihan menterjemahkan sekaligus melihat kemampuan siswa dalam mengingat pembelajaran yang telah dipelajari.

Tujuan pengajar menggunakan metode GTM agar siswa tidak hanya mampu menguasai bahasa Jepang, namun mampu memahami apa yang disampaikan sesuai dengan terjemahan ke dalam bahasa Indonesia. Dengan metode GTM ini siswa dengan mudah memahami materi yang telah disampaikan.

\section{2) Direct method}

Direct method merupakan metode dengan berbicara langsung dengan bahasa target. Proses belajar mengajar menggunakan direct method dilakukan secara langsung menggunakan bahasa target tanpa bantuan terjemahan bahasa ibu. Hal ini dapat meningkatkan motivasi belajar bahasa Jepang siswa dan merangsang siswa untuk berbicara menggunakan bahasa direct method Jepang.

Penggunaan saat proses pembelajaran dilakukan pada bagian-bagian tertentu pada kegiatan pembelajaran. Kegiatan menggunakan direct method yaitu pada kegiatan tanya jawab. Tanya jawab dilakukan dengan menggunakan bahasa Jepang secara langsung tanpa menterjemahkan lagi ke dalam bahasa sumber. Siswa akan menjawab pertanyaan yang diberikan sesuai dengan pertanyaan yang diberikan menggunakan bahasa Jepang. Dengan kegiatan tanya jawab tersebut siswa diharapkan mampu menyimak yang disampikan oleh pengajar.

Kegiatan menggunakan direct method juga dilakukan pada saat kaiwa atau percakapan. Kegiatan kaiwa dilakukan dengan menggunakan bahasa Jepang. Dengan kaiwa siswa dapat meningkatkan keterampilan komunikasi menggunakan bahasa Jepang secara langsung tanpa adanya proses menterjemahkan. Kegiatan kaiwa ini dilakukan sebagai bagian dari peningkatan komunikasi siswa seiring dengan pemahaman tata bahasa dan pengucapan yang benar.

Tujuan pengajar menggunakan direct method agar keterampilan komunikasi bahasa Jepang siswa meningkat dan pelafalannya dapat menyerupai lafal orang Jepang. Dengan teknik menirukan dan melafalkan kosakata, kalimat dan percakapan akan lebih membantu siswa dalam memantapkan bahasa Jepangnya.

\section{3) Metode Audiolingual}

Dalam proses pembelajaran metode audiolingual sering digunakan pada pengenalan kosakata baru dan pola kalimat baru yang dilatih secara berulang-ulang. Pengenalan kosakata baru dan pola kalimat oleh pengajar dilakukan secara lisan, siswa akan mengulangi ucapan dari guru dalam bahasa Jepang. Sehingga siswa terbiasa mendengar dan berbicara menggunakan bahasa sasaran. Penggunaan metode audiolingual ditekankan pada keterampilan menyimak dengan latihan secara berulang-ulang dalam pelafalan kata, latihan pola kalimat.

Metode audiolingual dilakukan pada saat latihan pengulangan dalam mengucapkan kosakata. Siswa terlebih dahulu menyimak ucapan kosakata dari pengajar kemudian ditirukan. Pada setiap pengucapan siswa, pengajar akan mengamati cara pengucapan siswa, jika terjadi kesalahan siswa dalam mengucapkan, pengajar akan memberikan contoh pengucapan yang tepat kepada siswa secara berulang hingga pengucapan pelafalan siswa tepat. Penggunaan metode audiolingual dilakukan saat membaca kalimat. Siswa akan membaca kalimat sesuai dengan apa yang didengar. Pengajar akan mengucapkan kalimat yang ada di buku sesuai dengan materi, siswa terlebih dahulu menyimak ucapan pengajar kemudian menirukannya. Siswa lebih sering dilatih dalam menirukan ucapan pengajar. Siswa yang menyimak dengan baik akan mampu menunjang keterampilan berbicara, membaca dan menulis.

Kegiatan pembelajaran menggunakan metode audiolingual, awalnya siswa harus terbiasa belajar dengan menyimak kemudian diikuti denga berbicara, membaca dan menulis. Melalui proses menyimak, siswa dapat berkomunikasi dengan baik. Siswa dituntut untuk menirukan ucapan pengajar. Materi yang diberikan bertahap dari materi yang mudah ke materi yang sulit. 
Tujuan pengajar menggunakan metode audiolingual agar siswa mudah dalam menggunakan bahasa sebagai alat komunikasi. Pada awalnya siswa hanya menyimak atau mendengar kemudian menirukan sesuai pelafalan. Setelah itu, membaca dan menulis baru diajarkan. Dengan kegiatan mendengar-mengucapkan ini diperlukannya kebiasaan diulang berkali-kali.

Dalam pembelajaran bahasa Jepang, pengajar tidak hanya menggunakan metode pembelajaran, namun menggunakan strategi dalam pembelajaran bahasa Jepang. Strategi yang digunakan oleh pengajar dalam proses pembelajaran yaitu, antara lain.

\section{1) Strategi Menggunakan Drill}

Strategi drill digunakan pada setiap proses pembelajaran bahasa Jepang. Pengajar menggunakan drill dari awal sampai akhir kegiatan pembelajaran. Strategi drill dapat digunakan untuk memberikan kesempatan kepada siswa berbicara dan meningkatkan keterampilannya, karena siswa dituntut untuk mampu berbicara dengan bahasa target dengan baik. Dalam penggunaan drill pengajar melakukan kegiatan dengan cara memberikan latihan pengulangan kosakata maupun pola kalimat baru secara berulang sehingga siswa dapat melafalkan kosakata maupun pola kalimat dengan benar serta dapat mengingatnya. Dengan strategi drill sangat memudahkan siswa dalam memahami kosakata dan kalimat dalam bahasa Jepang.

Pengajar memberikan drill berupa melatih pengucapan dan pelafalan siswa mengenai kosakata dan kalimat. Siswa yang kesulitan dalam melafalkan kosakata dan kalimat diminta untuk mengikuti ucapan pengajar dengan tepat. Cara ini bisa disebut dengan repetition drill. Adapun penerapannya yaitu sebagai berikut.

Pengajar :" Asoko ni posuto ga arimasu"

Siswa : "Asoko ni posuto ga arimasu"

Selain itu, pengajar juga menerapkan drill lainnya yaitu substitution drill. Penggunaan drill ini dilakukan ketika latihan pola kalimat, dimana contoh kalimat yang sudah ada sebagian katanya diganti dengan model yang ditunjuk. Penggunaan substitution drill biasanya dilakukan saat menjawab soal pada buku bahan ajar. Kalimat-kalimat tersebut akan diganti sebagian katanya (kata benda, kata kerja, kata sifat, dan lain-lain) sesuai dengan gambar yang sudah tertera.

Pengajar juga menggunakan jenis driil lainnya yaitu transformation drill. Teknik ini, siswa diberikan kosakata atau kalimat kemudian mengubahnya ke dalam bentuk yang sudah ditentukan. Penggunaan strategi transformation drill ketika pengajar memberikan kosakata kemudian kosakata tersebut diubah ke dalam bentuk kosakata yang sudah ditentukan. Kegiatan ini digunakan untuk memastikan kemampuan siswa dalam mengubah kosakata. Contoh penerapannya yaitu antara lain.

$\begin{array}{ll}\text { Pengajar } & \text { : "Wakal" } \\ \text { Siswa } & \text { : "Wakakute" } \\ \text { Pengajar } & \text { : "Nagal" } \\ \text { Siswa } & \text { : "Nagakute" }\end{array}$

Tujuan dari penggunaan strategi repetition drill, substitution drill dan transformation drill, yaitu untuk memberikan keterampilan dalam menghapal kosakata dan meningkatkan kemampuan membaca dan berbicara siswa, serta mendorong kemampuan siswa dalam mengubah bentuk kosakata. Selain itu, dengan pengajaran yang baik daya pikir siswa semakin lama semakin baik, maka siswa lebih teratur dan teliti dalam mendorong daya ingatnya.

\section{2) Strategi Menggunakan Tanya Jawab}

Berdasarkan observasi di kelas, strategi tanya jawab digunakan guru untuk mengetahui respon siswa mengenai materi yang diajarkan. Strategi tanya jawab juga digunakan ketika siswa bertanya kepada pengajar apabila ada materi yang belum dipahami. Kegiatan tanya jawab dapat dilakukan dengan menggunakan bahasa Indonesia maupun bahasa Jepang mengenai kosakata ataupun kalimat. 
Dalam proses pembelajaran bahasa Jepang, pengajar juga menggunakan strategi tanya jawab dalam memberikan pembelajaran di dalam kelas. Tujuan penggunaan strategi tanya jawab untuk melatih penguasaan kosakata dan pola kalimat yang sudah diajarkan serta mengetahui seberapa jauh kemampuan siswa dalam menguasai materi pelajaran. Strategi tanya jawab dilakukan pada seluruh siswa ataupun perorangan untuk menjawab pertanyaan yang diberikan oleh pengajar. Contoh penggunaan strategi tanya jawab, yaitu.

Pengajar : "Minasan, ano e ga o mite. Sensei wa doko ni imasuka?"

Siswa : "Kadek buchou to Carik sensei no aida ni imasu."

Kegiatan tanya jawab dapat membuat siswa menjadi lebih aktif dan kemampuan berbicara siswa akan terlihat. Hal ini dilakukan untuk mendapatkan respon dari siswa terkait pemahaman siswa penggunaan kosakata dan pola kalimat yang telah diajarkan.

Dengan strategi tanya jawab siswa dan guru saling berinteraksi langsung secara aktif dalam proses pembelajaran. Pelaksanaan strategi tanya jawab yang diterapkan berupa pertanyaan sederhana yang berkaitan dengan materi yang diajarkan. Siswa ada yang mampu menjawab dengan benar da nada juga siswa yang salah dalam menjawab. Kesalahan tersebut terjadi karena siswa kurang fokus dalam memahami materi yang disampaikan. Dengan tanya jawab pengajar dapat mengetahui sejauh mana pemahaman siswa terhadap materi yang dijelaskan. Siswa juga terlatih dalam bertanya, karena guru memberikan kesempatan kepada siswa untuk bertanya mengenai materi yang belum dipengerti.

\section{3) Strategi Menggunakan Pemberian Tugas}

Penggunaan strategi pemberian tugas dilakukan pada seluruh hasil observasi yang dilakukan. Pengajar memberikan tugas kepada siswa sebelum pembelajaran berakhir dan pengajar selalu mengoreksi tugas yang diberikan. Tugas yang diberikan berupa kosakata, pola kalimat ataupun menjawab soal-soal sesuai dengan materi yang telah diajarkan. Pemberian tugas bertujuan untuk meningkatkan kemampuan siswa terhadap materi yang telah dipelajari.

Sebelum pembelajaran berakhir, pengajar akan mengintruksikan tugas yang harus dikerjakan oleh siswa dengan cara menjelaskan secara langsung. Tugas tersebut dikerjakan secara individu atau kelompok. Tugas yang diberikan dapat dikerjakan di rumah, di sekolah, atau tempat lainnya. Dalam pemberian tugas ini siswa dapat terangsang lebih aktif untuk belajar secara individu atau kelompok agar hasil belajar siswa meningkat. Dengan mengerjakan tugas, siswa dapat melatih kembali di rumah mengenai materi yang sudah diajarkan. Pemberian tugas ini terbukti mampu meningkatkan hasil belajar siswa mengenai kosakata dan pola kalimat. Siswa tidak hanya belajar di dalam kelas saja namun juga belajar di luar jam pelajaran.

Setiap proses pembelajaran terkadang terdapat kendala, hambatan atau masalah yang dihadapi oleh setiap pengajar. Jati (2014) hambatan atau kendala dalam proses pembelajaran bisa datang dari berbagai faktor seperti faktor internal dan eksternal. Faktor internal merupakan hal-hal yang mempengaruhi proses belajar dari dalam diri yang sedang melakukan proses belajar. Faktor internal meliputi minat, bakat, motivasi dan kesiapan. Sedangkan faktor eksternal merupakan hal-hal yang mempengaruhi dari luar diri. Faktor eksternal meliputi metode mengajar, waktu belajar, keadaan sekolah dan media pembelajaran.

Berdasarkan hasil observasi dan wawancara yang telah dilakukan, kendala dalam pembelajaran di LPK Bulan Palapa yaitu kemampuan pemahaman siswa berbeda-beda. Ada siswa yang dapat mencapai pemahaman pelajaran tanpa adanya kesulitan, namun tidak sedikit siswa yang dapat mengalami kesulitan. Sehingga guru harus menyadari bahwa setiap siswa memiliki perbedaan kemampuan yang harus diperhatikan oleh guru agar dalam proses pembelajaran dapat berjalan dengan aktif. Jika pengajar menjelaskan materi mengikuti siswa yang kesulitan dalam memahami materi pelajaran, maka membutuhkan waktu yang lama. Apabila guru menjelaskan materi mengikuti siswa yang mudah dalam memahami materi, maka siswa yang kurang akan bertambah tidak mengerti. Sehingga guru harus menyelaraskan pembelajaran yang disampaikan agar semua siswa paham akan materi 
pelajaran. Upaya yang dapat dilakukan oleh pengajar ialah merancang pelajaran bagi siswa yang lambat, menghafal kosakata, serta penggunaan metode dan strategi yang tepat, memberikan tugas atau pekerjaan rumah secara rutin, dan mengadakan tes sebelum atau sesudah pelajaran. Hal ini bertujuan untuk meningkatkan kemampuan pemahaman siswa dalam proses pembelajaran.

Kendala yang lainnya yaitu ketidakhadiran beberapa siswa pada proses pembelajaran. Siswa yang tidak hadir dalam proses pembelajaran akan sulit meraih prestasi belajar atau pemahaman pelajaran di sekolah. Ketidakhadiran siswa dapat menimbulkan kurang efektif dalam menjalin komunikasi dalam menyampaikan materi secara sempurna sehingga tidak ada peningkatan prestasi belajar. Hal yang dapat dilakukan pengajar untuk meminimalisir ketidakhadiran siswa dalam pembelajaran dengan pengoptimalan penggunaan tata tertib sekolah, menjadikan kehadiran sebagai syarat kelulusan, bekerjasama dengan orang tua siswa dalam kehadiran dan kemajuan belajar siswa.

\section{Simpulan dan Saran}

\section{a. Kesimpulan}

Berdasarkan hasil penelitian dan pembahasan mengenai pembelajaran bahasa Jepang di LPK Bulan Palapa desa Landih Bangli dapat disimpulkan sebagai berikut.

1. Metode pembelajaran yang digunakan oleh pengajar bahasa yaitu metode Grammar Translation Method (GTM) digunakan ketika memperkenalkan kosakata dan pola kalimat dengan menterjemahkan kosakata dan kalimat yang sudah diajar ataupun sedang diajarkan dari bahasa Jepang ke dalam bahasa Indonesia atau sebaiknya. Direct method digunakan ketika proses pembelajaran kaiwa dengan menggunakan bahasa Jepang langsung tanpa proses menterjemahkan lagi ke dalam bahasa sumber, dan metode audiolingual yang digunakan ketika menperkenalkan kosakata baru dan pola kalimat baru dengan cara menyimak ucapan pengajar kemudian menirukannya yang dilatih secara terus menerus. Latihan ini akan mengakibatkan siswa menjadi kebiasaan dalam menggunakan bahasa sasaran.

2. Strategi pembelajaran yang digunakan oleh pengajar bahasa Jepang ialah drill, tanya jawab dan pemberian tugas. Strategi drill digunakan ketika memperkenalkan kosakata dan membuat kalimat sesuai dengan pola kalimat. Drill dilakukan secara bertahap dan berulangulang demi meningkatkan ingatan siswa akan kosakata dan pola kalimat. Strategi tanya jawab digunakan untuk mendapatkan respon dari pertanyaan yang diberikan oleh pengajar. Penggunaan strategi tanya jawab untuk mengetahui sejauh mana penguasaan materi pelajaran bahasa Jepang yang telah diajarkan atau sedang diajarkan. Strategi pemberian tugas dapat meningkatkan pelajaran yang sudah dipelajari. Pemberian tugas dapat merangsang pemahaman siswa dalam materi pembelajaran. Tugas yang sering diberikan oleh pengajar adalah tugas tertulis seperti menjawab soal-soal yang ada di buku penunjang.

3. Kendala dalam proses pembelajaran bahasa Jepang yang paling mempengaruhi yaitu kemampuan pemahaman siswa berbeda-beda. Ada siswa yang dapat mencapai pemahaman pelajaran tanpa adanya kesulitan, namun tidak sedikit siswa yang dapat mengalami kesulitan. Sehingga guru harus menyadari bahwa setiap siswa memiliki perbedaan kemampuan yang harus diperhatikan oleh guru agar dalam proses pembelajaran dapat berjalan dengan aktif. Upaya yang dapat dilakukan oleh pengajar ialah merancang pelajaran bagi siswa yang lambat, menghafal kosakata, serta penggunaan metode dan strategi yang tepat, memberikan tugas atau pekerjaan rumah secara rutin, dan mengadakan tes sebelum atau sesudah pelajaran. Hal ini bertujuan untuk meningkatkan kemampuan pemahaman siswa dalam proses pembelajaran.

\section{b. Saran}

Berdasarkan hasil temuan selama melaksanakan penelitian ini, maka ada beberapa saran yang perlu disampaikan, yaitu sebagai beriku. 
1. Sebagai pengajar di LPK Bulan Palapa diharapkan mampu menggunakan berbagai variasi strategi pembelajaran agar minat siswa dalam belajar bahasa Jepang menjadi meningkat dan dapat menciptakan suasana menyenangkan di dalam kelas saat proses pembelajaran.

2. Pengajar hendaknya mampu menggunakan media pembelajaran lainnya seperti kartu gambar ataupun video. Penggunaan media pembelajaran selain buku dan papan tulis dapat memberikan inovasi dalam pembelajaran. Media pembelajaran dapat membantu siswa dalam meneriman materi dan membantu pengajar dalam menyampaikan materi menjadi lebih menarik.

\section{Daftar Pustaka}

Adiatman. 2011. Efektifitas Penerapan Metode Pemberian Tugas (Resitasi) Terhadap Hasil Belajar Siswa Dalam Mata Pelajaran Biologi Kelas XI IPA SMA Negeri 1 Sungguminasa Kabupaten Gowa. Skripsi. Jurusan Pendidikan Biologi, Fakultas Tarbiyah dan Keguruan Uin Alauddin Makassar.

Anggriani, Risva. 2017. Keefektifan Metode Role Playing Terhadap Keaktifan dan Kerja Sama Siswa Dalam Pembelajaran IPS. Harmoni Sosial.Volume 4. Nomor 2 (Hal 212221)

Astina, I Ketut Widi. 2019. Profil Strategi Pembelajaran Bahasa Jepang di LPK Terakoya Bali. Skripsi. Program Studi Pendidikan Bahasa Jepang, Jurusan Bahasa Asing, Fakultas Bahasa dan Seni, Universitas Pendidikan Ganesha, Singaraja.

Astutik, Yuli. 2017. "Metode Total Physical Response (TPR) pada Pengajaran Bahasa Inggris Siswa Taman Kanak-kanak". http//dx.doi.org/10.17509/bs_jpbsp.v17i2.9658, Volume 17, Nomor 12 (hal.196-207)

Basrudin, dkk. 2013. Penerapan Metode Tanya Jawab untuk Meningkatkan Hasil Belajar Siswa Pokok Bahasan Sumber Daya Alam di Kelas IV SDN Fatufia Kecamatan Bahodopi. Kreatif Tadulako Online. Volume 1, Nomor 1 (hal 214-227)

Budiarso, Iwan. 2019. Analisis Metode Communicative Language Teaching Terhadap Kemampuan Berbicara Bahasa Inggris Guru-Guru SMK dan SMP Islam Mandiri Bojong Gede Bogor. SAP. Volume 3. Nomor 3 (hal 239-247).

DPN SBMI. 2020. Daftar Sending Organization atau LPK Pemagangan Jepang. Tersedia di https://sbmi.or.id/?p=10809 (Diakses pada 13 November 2020)

Fuadah, Evi Nur. 2014. Efektivitas Metode Audiolingual untuk Meningkatkan Penguasaan Bahasa Jepang di SMA Negeri 1 Ungaran. Skripsi. Prodi Pendidikan Bahasa Jepang, Jurusan Bahasa Asing dan Sastra Asing, Fakultas Bahasa dan Seni, Universitas Negeri Semarang

Irwan, dkk. 2018. Penerapan Metode Diskusi dalam Peningkatan Minat Belajar. IQRO. Volume 1, Nomor 1 (hal 43-54)

Jati, Aufrida Wulan Cahyeng. 2014. Faktor-Faktor Penghambat Proses Pembelajaran Biola Grade 1 di Jogja Music School (JMS) Yogyakarya. Skripsi. Jurusan Pendidikan Musik, Fakultas Baahasa dan Seni, Universitas Negeri Yogyakarta.

Kartikasari, Dewi. 2017. Peningkatan Hasil Belajar Siswa dalam Pelajaran Bahasa Inggris Melalui Metode Kerja Kelompok di SMP Negeri 3 Palembang. Wahana Didaktika. Volume 15, Nomor 3 (hal 42-52) 
Lailaa, Hikmatul. 2016. Penerapan Metode Community Language Learning di Luar Kelas dalam Pembelajaran Mahárah Al-Kalám. Skripsi. Pendidikan Bahasa Arab, Fakultas IImu Tarbiyah dan Keguruan, Universitas Islam Negeri Sunan Kalijaga

Padmadewi, Ni Nyoman. 2012. Strategi Pembelajaran Bahasa. Singaraja: Undiksha.

Romadhon, Beril Firmansyah. 2018. Mode Pendidikan Nonformal Lembaga Bimbingan Belajar Mentari IImu 3 Kecamatan Sukun Kota Malang. Skripsi. Jurusan Pendidikan IImu Pengetahuan Sosial, Fakultas IImu Tarbiyah dan Keguruan, Universitas Islam Negeri Malik Ibrahim Malang.

Sari, Mila. 2016. "Pengaruh Penerapan Metode Pembelajaran Drill and Practive Terhadap Aktivitas Belajar Siswa (Studi Kasus Mata Pelajaran Akuntansi Pokok Bahasan Jurnal Umum Kelas X SMAN 5 Kota Sukabumi Tahun Ajaran 2015-2016) ". Skripsi.. Program Studi Pendidikan Ekonomi (Bidang Keahlian Khusus Pendidikan Akuntansi) Fakultas Keguruan dan Ilmu Pendidikan Universitas Pasudan, Bandung.

Septyana, Hardike. 2013. Manajemen Pembelajaran Berbasis Kompetensi Pelatihan Menjahit di Lembaga Pelatihan Kerja Swasta (LPKS) Fortuna Dukuh Siberuk Desa Siberuk Kabupaten Batang. Journal of Nonformal Education and Community Empowerment. Volume 2, Nomor 2 (Hal 46-50)

Sodiqin, Ahmad. 2015. Pengaruh Pembelajaran Kooperatig Metode Scramble Terhadap Hasil Belajar IPS di Sekolah Dasar. Artikel Penelitian. Program Studi pendidikan Guru Sekolah Dasar, Jurusan Pendidikan Dasar, Fakultas Keguruan dan IImu Pendidikan, Universitas Tanjungpura Pontianak

Sulasamono, Bambang Suteng. 2012. Problem Solving: Signifikansi, Pengertian dan Ragamnya. Satya Widya. Volume 28, Nomor 2 (hal. 155-165)

Tambak, Syahraini. 2014. Metode Ceramah: Konsep dan Aplikasi pembelajaran Pendidikan Agama Islam. TARBIYAH. Volume 21, Nomor 2 (hal 375-401)

The Japan Foundation. 2018. Survey Report on Japanese Language Education Abroad 2018. Tersedia pada https://www.jpf.go.jp/e/project/japanese/survey/result/survey18.html (diakses pada 24 September 2020) 